VISIONARY PRAGMATISM 



\title{
VISIONARY PRAGMATISM
}

\author{
Radical and Ecological Democracy \\ in Neoliberal Times
}

ROMAND COLES

DUKE UNIVERSITY PRESS

Durham and London 2016 
(C) 2016 Duke University Press

All rights reserved

Printed in the United States of America on acid-free

paper $@$

Typeset in Minion Pro and Gill Sans by Graphic

Composition, Inc., Bogart, GA

Library of Congress Cataloging-in-Publication Data

Coles, Romand, [date] author.

Visionary pragmatism : radical and ecological democracy in neoliberal times / Romand Coles.

pages $\mathrm{cm}$

Includes bibliographical references and index.

ISBN 978-0-8223-6049-o (hardcover : alk. paper)

ISBN 978-0-8223-6064-3 (pbk. : alk. paper)

ISBN 978-0-8223-7466-4 (e-book)

1. Democracy-United States-Citizen participation.

2. Democracy-Social aspects-United States.

3. Capitalism-Social aspects-United States.

4. Capitalism-Environmental aspects-United States.

5. Capitalism-Political aspects-United States.

6. Community organization-United States. I. Title.

JC423.C6476 2016

$320.973-\mathrm{dc} 23$

2015035886

Cover art: Detail of 8osw Iridescent / Flying Garden / Air-Port-City (2011) installed in Tomás Saraceno: Cloud-Specific at the Mildred Lane Kemper Art Museum, Washington University in St. Louis (September 9, 2011-January 9, 2012). Courtesy the artist, Esther Schipper Gallery, Berlin; Pinksummer contemporary art, Genoa; Tanya Bonakdar Gallery, New York; Andersen's Contemporary, Copenhagen. Photo by Whitney Curtis. 


\section{THIS BOOK IS DEDICATED TO}

\section{MY DAUGHTER AVIVA ASPEN HARO-COLES,}

BORN ON AUGUST 5, 2015.

In the beautiful aura of her emergent, exuberant, and full-bodied efforts to live into the world, I marvel in deepest love at the traces of ancestors she will never know and future possibilities beyond the reach of my wildest imagination. 
